\title{
e- Health - Guidelines for State Policy Formation in the Healthcare Sector of Bulgaria
}

\author{
Vyara Tserovska ${ }^{1}$, Stoyan Denchev ${ }^{2}$ \\ ${ }^{1,2}$ University of Library Studies and Information Technologies, Sofia, Bulgaria \\ viara_tserovska@abv.bg,s.denchev@unibit.bg
}

\begin{abstract}
The active reform of the Bulgarian society requires new approaches and full use of information processes for management in the healthcare system. Despite the transformations that have taken place in this area, many issues are yet to be resolved. EHealth is a collection of applications based on advanced information and communication technologies within an organisational and legal framework covering the whole aspect of healthcare, from diagnosis to the time of completion and payment for the treatment. The inconsistencies identified between the high requirements of modern health care, the need to implement the eHealth and the significant falling behind of the project implementation process can only be addressed by implementing a national strategy regulating the objectives, scope and stages of the creation of a single intergrated health information system.
\end{abstract}

Keywords: e-Health; information processes; healthcare; management; system; society; health services

\section{Introduction}

e-Health plays an important role in modernising the healthcare systems, achieving a more efficient management and control as well as a more efficient spending of financial resources, and improving the quality of health services provided to the population (Borisov, 2005). The implementation of high-tech solutions helps achieve a better use of financial resources in the healthcare system and reduce inefficient costs. It also ensures a greater transparency in health care, making it possible to strictly monitor the activities in the sector and to limit unregulated payments and corruption. The effectiveness and quality of the healthcare services provided is increased by raising awareness among patients and their relations with people employed in the healthcare sector (Vukov, 2007).

\section{Research Methods}

At present, Bulgaria does not have an integrated health information system to meet the challenges posed by our EU membership. The information system in the Bulgarian healthcare sector comprises the information system of the National Health Insurance Fund (NHIF), of the health network, the public health system and the medical records of patients. These components, together with the electronic health card, are an absolute necessity both in Bulgaria and in the European Union.

The integrated information system should be linked and complementary to other national security related departments (Galev et al., 2004). The application of telemedicine and other electronic communication technologies makes it possible to remove all obstacles to the access to and to ensure timeliness and high quality of medical care (Deneva et al., 2003). 


\section{Discussion}

Individual stages or projects for the creation of an integrated information system (IIS) have been carried out so far but they are of a rather chaotic nature (Kovacheva, 2009). Figure1 presents the whole picture of a developed eHealth, which is our goal.

Further on, we present a description of the projects implemented so far and a proposal for a single National Strategy for the implementation of eHealth in Bulgaria.

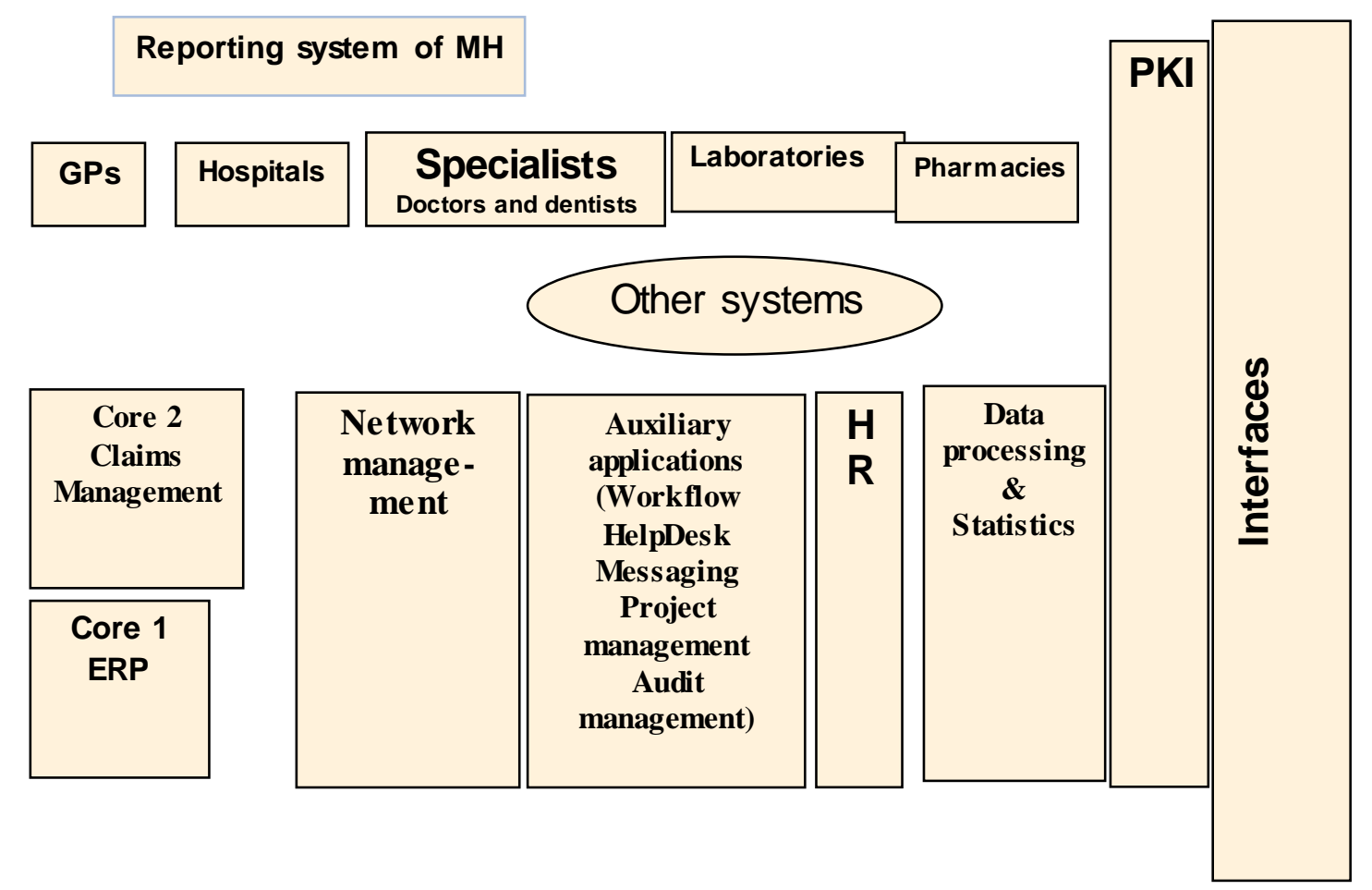

Figure 1. eHealth in Bulgaria - overview

As follows from Fig.1, the necessary software and parts of the integrated health information system include:

A. Core 1 and 2IIS of the NHIF

B. Network management - part of the IIS of the NHIF

C. Auxiliary applications

D. Human resources management - part of IIS of the NHIF

E. Data processing and statistics - part of IIS of the NHIF

F. Software for the various medical care providers (MCPs) - GPs, hospitals, specialists - doctors and dentists, laboratories and pharmacies

G. Reporting system for the Ministry of Health - software of the Health Information Centre (HIC)

H. PKI - an encoding (through encryption) and decoding system - for the whole IS

I. Electronic (smart) card software (Patient File)-for the whole IS

J. Interfaces - HIC, NSSI (National Social Security Institute), NSI (National Statistics Institute), Police, CRAS (Civil Registration and Administrative Services), MF (Ministry of Finance), Parliamentary Healthcare Committee, etc. 
Projects implemented in the country so far are insufficient to develop and improve a comprehensive national healthcare system, as presented in Figure 1.

According to the recommendations given by the international consultants, the projects that need to be implemented or are still incomplete are:

- Building up a Data Warehouse for the entire national healthcare system - a very important part of this system is the creation of the database according to the international requirements with regard to the patient file (Kiryakov, 2010);

- Delivery of communication equipment for the NHIF and the establishment of a backup centre;

- Delivery of communication equipment for the MF;

- Implementation of auxiliary applications (Document Turnover, Help Desk, Messaging, Audit and Project Management) for the MF and the NHIF;

- Deployment of e-cards - a solution for the entire health information system (including the MF, the NHIF as well as the medical and other health care providers), based on an electronic patient file;

- We are increasingly witnessing the integration of modern technologies in the environment of intergroup communication: the electronic health card, telemedicine consultations, 3D technologies and others. (Tserovski, 2019)

- Deployment of a PKI solution and portal technologies for the entire national health information system.

The inconsistencies identified between the high requirements of modern health care, the need to implement the eHealth and the significant falling behind of the project implementation process can only be addressed by implementing a national strategy regulating the objectives, scope and stages of the creation of a single integrated health information system. Key healthcare projects in Bulgaria (Ognyanov, 2010)

\section{NHIF}

The integrated information system of the NHIF includes (Ognyanov, 2010):

- Handling of claims from medical service providers;

- Medical and financial control;

- National registers;

- Regulatory standards;

- Statements.

This information system could be viewed as a basis for future applications and development due to the following features (Ognyanov, 2008):

- The large-scale and highly classified information database on medical activities carried out by medical care providers;

- The implemented link: medical work performed - insured person;

- Guaranteed frequency and regularity of new information entry;

- A sustainable information infrastructure in place that allows new IT applications to be built up according to the priorities set;

- A personalised information system that includes administrative and health information for each insured person who has used medical services paid by the NHIF. ( Bogova, H., B. Bogov, 2017).

The NHIF has a health portal with the following functionalities:

Web-based reporting from medical care providers (MCPs); 
Portal interface for access to nomenclatures and lists kept by the NHIF (Pilosof, 2010).

- Portal interface to review patient data;

- Content management-based information services.

\subsection{Ministry of Health}

To date, a number of projects have been implemented in the MF, which are considered to be suitable for the building of subsequent applications or for the generation of individual modules (Tsekov, 2008):

- A geo-based information system to support the creation and maintenance of a National Health Map of the Republic of Bulgaria /GIS of NHM/ and the building of a subsystem to be used by healthcare facilities to publish information on the Internet (Gigov, Stoycheva, 2010);

- A centralised drug-allocation information system to cover all patients pursuant to Ordinance No 34/25.11.2005 on the treatment to be paid by the national budget (outside the scope of compulsory pension insurance);

- Setting up a national electronic health portal and implementing a personal electronic health record for 40,000 public administration officials.

\section{Conclusion}

\section{1 eHealth Priority Areas (Ognyanov, 2007)}

eHealth plays an essential role for the successful implementation of the health reform in Bulgaria. This means that projects and services should be developed in three main areas:

- To support the activities of medical care providers (MCPs), which will ease their administrative obligations and increase the time for actual medical activities;

- For health insurance institutions that will pay for medical activitiesactually performed, will be able to plan their budgets effectively and optimise the costs on the basis of real-time MCP reports;

- For insured persons and patients. To be successfully implemented, it is important that this reform is supported by the Bulgarian citizens, i.e. that they are on the side of the reform. This means that they should be informed and given easier access to high quality medical services. The current trend is that the patient, on the basis of health information available in an accessible form, in conjunction with the physician, determine their diagnosis and method of treatment (Mircheva, 2002).

The development of these three directions will provide an opportunity to implement:

An electronic health insurance card which will allow a reliable identification of the insured person and authorisation of the provision and receipt of the healthcare service by the insured person;

E-prescriptions and referrals which will reduce the risk of prescribing inadequate medications, enhance the control over the funds spent on such medications, track the patient's pathway and adequacy of the diagnosis upon hospitalisation, and ensure a more efficient spending of inpatient care funds (Kostov, 2007).

Real-time on-line submission of MCP reports, immediately after completing the check-up, which will eliminate the need for MCPs to physically visit the regional health insurance funds.

On-line booking of appointments and SMS reminder system. In the Euro Health Consumer Index 2009 report which was published in October 2009, the lack of this option was indicated as a negative for Bulgaria. The project envisages that patients will book 
appointments based on the MCPs' working schedules published on-line (Karakanovski, 2009).

Access for citizens to understandably described medical activities for individual diseases. A similar approach has been applied in England ('Healthguides' - the Map of Medicine Evidence Based Clinical Knowledge System) (Kyuchukova, 2009).

All institutions need to join forces to find tools and resources for the deployment of ICT systems in health care, as very often the projects are complex and involve more than one institution.

\section{References}

1. Богова, Христина, Борис Богов. (2017). Комуникационни особености при общуването лекар- пациент. сп. "Съвременна медицина", бр. 1, С., ISSN 0562 7192.

2. Борисов, В. Здравен мениджмънт. (2005). Азбука на здравния мениджмънт. С., Филвест, с. 278

3. Борисов, В. (2005). Стратегическият мениджмънт - дефицит на здравната реформа. - Здравен мениджмънт, том 5, № 6, 3-5

4. Вуков, М. (2005). Концептуален модел за здравна информация в България. Социална медииина, XIII, № 1-2

5. Вуков, М. (2007). Съвременни тенденции в развитието на медицинските информационни системи. Социална медицина, XV, № 2, 37-41.

6. Галев, А. и съавт. (2004). Модел за изграждане на интегрирана автоматизирана информационна система във връзка с новите приоритети в дейността на службата по трудова медицина при Центъра по военна епидемиология и хигиена - BMA. Военна медицина, LVI.

7. Гигов, Кр., В. Стайчева. (2010). ГИС за нуждите на медицинското осигуряване при екстремни ситуации. Шеста национална конференция „Ездравеопазване - от инвестицията до качествената промяна", 17.02.2010 г., София

8. Денева, В. и съавт. (2003). Система за телемедицина. Научни трудове на НВУ „В. Левски“, 73, № 1, с. 389-394.

9. Денева, В.и съавт. (2003). Единна телемедицинска информационна мрежа. Научни трудове на НВУ „В. Левски“, 73, № 1, с . 395-401.

10. Каракановски, Е. (2009). Иновативни решения в здравеопазването. Пета Национална конференция,Информационните технологии и комуникациите в здравеопазването - предизвикателство на XXI век”, 15.10.2009 г., София

11. Ковачева, С. (2009). Електронно здравеопазване в България - реалност и перспективи. Пета Национална конференция,„инормационните технологии и комуникациите в здравеопазването - предизвикателство на XXI век", 15.10.2009 г., София

12. Киряков, О. , О. Пишев. (2010).Практически опит в изграждането на националните системи за електронно здравеопазване чрез използване на Microsoft Connected Framework. Шеста национална конференция „Ездравеопазване - от инвестицията до качествената промяна", 17.02.2010г., София

13. Кючукова, Ив. (2009). Мобилни иновации за здравеопазването. Пета Национална конференция,Информационните технологии и комуникациите в здравеопазването - предизвикателство на XXI век”, 15.10.2009 г., София. 
14. Огнянов, А. (2007). Ролята на НЗОК в развитието на електронното здравеопазване. Втора Национална конференция "Информационни и комуникационни технологии в здравеопазването", 07.02.2007 г., София

15. Огнянов, Ал. (2010). Здравната реформа и готовността на съществуващите здравни информационни системи. Шеста национална конференция „Ездравеопазване - от инвестицията до качествената промяна", 17 февруари 2010 г. , София

16. Огнянов, Ал. (2008). Информационната система на НЗОК - база за изграждане на електронното здравеопазване в България. Трета Национална конференция "Информационни и комуникационни технологии за здравеопазването", 13.02.2008 г., София

17. Огнянов, Ал. (2007). Роля на НЗОК в развитието на електронното здравеопазване. Интернационална Конференция 'Налагане на стандарти в сферата на електронното здравеопазване. Интеграция на информационни системи, интероперабилити, защита на личните данни в сферата на електронното здравеопазване" 26 Юни 2007 г., София

18. Цеков, В. (2009). Електронното здравеопазване в България - постижения и планове. Балканска конференция по електронно здравеопазване "Трансгранични електронни здравни услуги", 12.02.2009, София.

19. Цеков, В. (2008). Обзор и анализ на постигнатото в сферата на ездравеопазването в България до момента и предварително обсъждане на бъдещите проекти на М3 в тази област. Трета Национална конференция "Информационни и комуникационни технологии за здравеопазването", 13.02.2008 г., София.

20. Цеков, В. (2007). Стратегия и план за действие за внедряване на електронното здравеопазване в България. Втора Национална конференция "Информационни и комуникационни технологии в здравеопазването", 07.02.2007 г., София.

21. Мирчева, И. (2009). E-Неalth и защита на правата на пациента. Социална медицина, XVII, № 1-2, 64-67

22. Мирчева, И. (2006). Медицинска информатика (избрани теми). Издание на МУ-Варна, стр.242

23. Мирчева, И.(2002). Медицинската информатика - лукс или необходимост. Българска медицина, Х, № 2, 22-24.

24. Ridzal Wahid, Florence Pribadi, Berlian Ester Wakas. (2020). Digital Activism:Covid-19 Effects in Campus Learning Budapest International Research and Critics in Linguistics and Education (BirLE) Journal Volume 3, No 3, August 2020, Page: 1336-1342 e-ISSN: 2655-1470 (Online), p-ISSN: 2655-2647 (Print)

25. Tserovski S, Georgieva S, Simeonov R, Bigdeli A, Röttinger H, Kinov P. Advantages and disadvantages of $3 \mathrm{D}$ printing for pre-operative planning of revision hip surgery. J Surg Case Rep. 2019;2019(7):rjz214.

26. Tiodora Fermiska Silalahi, Ahmad Fakhri Hutauruk. (2020). The Application of Cooperative Learning Model during Online Learning in the Pandemic Period. Budapest International Research and Critics in Linguistics and Education (BirLE) Journal Volume 3, No 3, August 2020, Page: 1336-1342 e-ISSN: 2655-1470 (Online), p-ISSN: 2655-2647 (Print) 